\title{
IMPLIKASI TAKDIR
}

\section{DALAM KEHIDUPAN MANUSIA}

\author{
Oleh: Suriati ${ }^{1}$ \\ ${ }^{1}$ Institut Agama Islam Muhammadiyah Sinjai, \\ Jl.Sultan Hasanuddin. No. 20 Balangnipa, Sinjai \\ E-mail: Suriatisuri802rocketmail.com, Tlp:+6281355983665
}

\begin{abstract}
$* * *$
Abstrak

Takdir adalah salah satu dari rukun iman yang tercantum di dalamnya. Sebagaimana paham ketentuan dan ketetapan itu ada, baik masalah Kematian, kelahiran, rizki, nasib, jodoh, bahagia, maupun celaka telah ditetapkan sesuai ketentuan-ketentuan Ilahiah yang tidak pernah diketahui oleh manusia dan semua itu harus diyakini adanya.Tulisan ini membahas bagaimana keyakinan kita terhadap takdir dan cara menyikapinya takdir baik maupun takdir buruk. Dengan kata kunci yaitu : bagaimana Implikasi Taqdir Bagi Kehidupan Manusia, hikmah dan Dampaknya, dan cara menikapi adanya takdir tersebut? Manusia hakekatnya itu merdeka, bebas menentukan perbuatannya dengan usahanya sendiri dan kemerdekaan manusia itu sendiri adalah merupakan kadar atau taqdir Allah ayat-ayat di atas, itupun sebenarnya secara implisit memberikan pengertian bahwa usaha yang sifatnya merdeka, itulah yang menentukan akibatnya. Namun tinggal masing-masing pribadi menyikapi dan menentukan jalan takdir yang dilalui, sebab telah hadir dalam diri manusia adanya keyakinan.
\end{abstract}

Kata Kunci: Implikasi, Takdir, Kehidupan

PENDAHULUAN

$\mathrm{K}$ onsep Takdir, selalu menjadi perdebatan dan pertanyaan banyak orang. Akhir-akhir ini cukup banyak pertanyaan ataupun diskusi-diskusi tentang takdir. Bagi umat islam, takdir Qadha dan Qadar, dimana kata takdir ini merupakan kata yang berasal dari Qadar. Karenanya, pemahaman tentang takdir ini sangat penting bagi seorang muslim. Sebab pemahaman tentang takdir ini akan menentukan arah dan sikap seorang muslim terhadap berbagai hal yang terjadi selama hidupnya.

Hidup ini memang penuh dengan warna. Dan ingatlah bahwa hakikat warna-warni kehidupan yang sedang kita jalani di dunia ini telah Allah tuliskan (tetapkan) dalam kitab "Lauhul Mahfudz" yang terjaga rahasianya dan tidak satupun makhluk Allah yang mengetahui isinya. Semua kejadian yang telah terjadi adalah kehendak dan kuasa Allah Swt. Begitu pula dengan bencana-bencana yang akhir-akhir ini sering menimpa bangsa kita. Gempa, tsunami, tanah longsor, banjir, angin ribut dan bencana-bancana lain yang telah melanda bangsa kita adalah atas kehendak, hak, dan kuasa Allah Swt. Dengan bekal keyakinan terhadap takdir yang telah ditentukan oleh Allah Swt., seorang 
mukmin tidak pernah mengenal kata frustrasi dalam kehidupannya, dan tidak berbangga diri dengan apa-apa yang telah diberikan Allah Swt..

Kematian, kelahiran, rizki, nasib, jodoh, bahagia, dan celaka telah ditetapkan sesuai ketentuanketentuan Ilahiah yang tidak pernah diketahui oleh manusia. Dengan tidak adanya pengetahuan tentang ketetapan dan ketentuan Allah ini, maka kita harus berlomba-lomba menjadi hamba yang saleh-muslih, dan berusaha keras untuk menggapai cita-cita tertinggi yang diinginkan setiap muslim yaitu melihat Rabbul'alamin dan menjadi penghuni Surga.

Keimanan seorang mukmin yang benar harus mencakup enam rukun. Yang terakhir adalah beriman terhadap takdir Allah, baik takdir yang baik maupun takdir yang buruk. Salah memahami keimanan terhadap takdir dapat berakibat fatal, menyebabkan batalnya keimanan seseorang.

\section{PEMBAHASAN}

\section{A. Implikasi Taqdir bagi Kehidupan Manusia}

Pada pembahasan terdahulu, yang menjadi masalah esensial bagi manusia adalah bagaimana manusia harus berusaha, bertindak sesuai dengan kehendaknya, adapun berhasil tidaknya usaha, tindakan tersebut, di sini berlaku kehendak Allah Swt.., tetapi dalam usaha itu manusia diberi Allah kebebasan. Jadi kebebasan itu pemberian dari Allah juga. Bila kehendak Allah dengan kehendak manusia sebagai pemberian Allah tersebut diharmoniskan atau dengan kata lain, bila kehendak manusia itu ditundukkan atau diatur dengan kehendak Allah, maka akan berjalan kehidupan manusia ini dengan selamat.

Persoalan kemanusiaan selalu berkaitan dengan persoalan nasib manusia, dan agaknya tidak ada komunitas manusia yang memasuki dunia pemikiran ilmiah dan filosofis tanpa berhadapan dengan persoalan itu. Begitu juga, tidak ada satu masyarakat pun yang memulai kehidupan pemikiran tanpa mempelajari persoalan itu.

Sewaktu masyarakat Islam mulai memasuki pemikiran ilmiah dengan bentuk yang cepat, mereka telah menempatkan persoalan jabr (keterpaksaan) dan ikhtiar (kebebasan) manusia dalam melakukan perbuatan-perbuatannya yang dikaitkan dengan kekuasaan Tuhan, menjadi amat penting. Ditambah lagi al-Qur'an sebagai undang-undang kehidupan umat Islam telah memunculkan banyak persoalan, misalnya tentang keterpaksaan dan kebebasan manusia, masalah kekuasaan Tuhan dan lain-lainnya. Karena al-Qur'an mengajak umat Islam bertadabbur dan bertafakur, maka umat Islam, suka atau tidak, harus berhadapan dan melakukan kajian yang mendalam terhadap persoalan tersebut.

Berbicara tentang masalah nasib manusia yang dikaitkan dengan kekuasaan Tuhan, maka ada dua aliran dalam teologi Islam yang sangat besar pengaruhnya, yaitu Qadariyah-Mutazilah dan Jabariyah-Asyariyah. Bagi Mutazilah, manusia mempunyai kebebasan dalam menentukan nasibnya sendiri. Sementara Asyariyah, manusia tidak mempunyai kebebasan dalam menentukan nasibnya sendiri. 
Dalam hidup keseharian, umat Islam tampaknya terpola dari pengaruh salah satu aliran tersebut di atas serta mempunyai implikasi bagi umat Islam secara universal, baik yang bersifat positif maupun yang negatif.

Menurut Harun Nasution, Mưtazilah yang menganut faham dan pandangan liberal tentang ajaran-ajaran Islam, hanya terikat pada ayat-ayat dan hadis-hadis yang qathi dan jumlahnya tidak banyak. Dengan demikian, ruang gerak dalam menyesuaikan hidup dengan perkembangan zaman dan perubahan kondisi dalam masyarakat bagi para penganutnya adalah luas. Para penganutnya tidak banyak menghadapi kesulitan-kesulitan dalam menyesuaikan hidup dengan perkembangan yang timbul dalam masyarakat modern, terutama dalam lapangan kemajuan ilmu pengetahuan dan teknologi.1 Dalam kata lain, dalam masyarakat yang menganut paham teologi liberal (Mutazilah), kemajuan dan pembangunan dapat berjalan lancar. Sebaliknya dalam teologi tradisional (Asyariyah), penganutnya sangat terbatas ruang geraknya karena mereka sangat terikat dalam mengartikan ayatayat secara tekstual, ayat-ayat yang mengartikan zhanni. Demikian para penganut sukar dapat mengikuti perkembangan dalam masyarakat modern, sehingga dapat dikatakan bahwa, teologi tradisional dapat merupakan salah satu faktor yang memperlambat kemajuan pembangunan.

Menurut Jalaluddin Rahman, konsep perbuatan manusia Mutazilah telah memberi peran penting kepada manusia. Ia dapat berbuat karena ia memiliki potensi dan daya. Perbuatannya terjadi atas pilihan dan keputusannya. Dengan begitu, Mutazilah menghendaki manusia untuk produktif. Bahkan disebutkan ia pelaku terhadap perbuatannya, memperlihatkan kelaikan. Karena itu, tanggung jawab manusia terhadap perbuatannya cukup logis.2

Dalam qadar itu ada sebab dan ada akibat, karena adanya ukuran, kekuatan, tabiat dan manfaat tertentu bagi tiap sesuatu akan membawa akibat-akibat tertentu pula. Karena itu Allah Swt.. memerintahkan kepada manusia untuk mencari sebab-sebab bagi ada atau berhasilnya sesuatu yang baik dan sebab-sebab untuk terhindar dari sesuatu yang buruk.3

Asyariyah dengan konsep kasbnya, berpendapat bahwa kasb terjadi karena daya yang diciptakan setiap diri berbuat. Pelaku kasb sesungguhnya adalah Tuhan, bahkan kasb itu ciptaan Tuhan. Ditambahkan bahwa daya manusia lemah dan daya Tuhan lebih dominan dalam perwujudan perbuatan manusia. Dengan demikian, Asyariyah tidak memberi peran penting dan melemahkan daya manusia. Maka bagaimana mungkin dia produktif-kreatif. Sebagai implikasinya, bahwa tanggung

1 Harun Nasution.

2 Jalaluddin Rahman, Konsep Perbuatan Manusia Menurut Qur'an; Suatu Kajian Tafsir Tematik, (Jakarta: Bulan Bintang, 1992) cet.I, h. 168

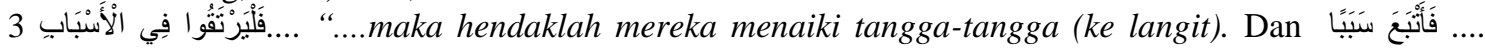
"maka diapun menempuh suatu jalan (sebab)..." 
jawab yang diakui oleh Asyariyah tidak laik bagi manusia. Oleh karena itu, tanggung jawab yang diakui oleh Asyariyah tidak logis.4

Konsep yang mengatakan bahwa perbuatan manusia tidak terkait dengan dirinya akan mengakibatkan kehancuran tatanan sosial sekaligus mengakibatkan keruntuhan hukum kausalitas alam.5 Jika perbuatan manusia dikaitkan pada Allah Swt.., hubungan sebab akibat menjadi hilang karena "dapat dibenarkan terjadinya sesuatu yang membutuhkan alat tanpa adanya alat itu sendiri".6 Allah Swt.. tidak memerlukan tangga untuk menciptakan "memanjatnya Zaid" dan tidak membutuhkan sayap untuk menciptakan "terbangnya burung", juga tidak membutuhkan pena dan tangan untuk menciptakan "menulis di atas kertas". Apabila demikian, ada dan tidak ada alat itu sama saja. Tidak ada alat juga tidak berpengaruh apa-apa. Bahkan tidak ada halangan bagi Allah untuk membuat aturan di suatu negeri di satu waktu tertentu bahwa orang yang tidak memiliki alat dapat melakukan sesuatu yang biasanya tidak bisa dilakukan. Ini karena Allah menciptakan pekerjaan, bukan alat untuk bekerja.7

Menurut Muhammad Abduh, sebagaimana yang dikutip oleh Muhammad al-Bahi, Bahwa sebagai akibat dari aqidah jabr, bukan saja seseorang yang merasa dirinya lemah dihadapan Tuhan, tetapi lemah juga dihadapan orang lain, karena aqidah jabr, pada hakekatnya hanya bisa hidup atas penghapusan kepribadian dan wujud diri sendiri.8 Meskipun seharusnya penghapusan itu hanya terjadi dalam hubungan dengan Tuhan saja, tetapi kelemahan pribadinya, sehingga menganggap bahwa penghapusan tersebut juga berlaku dalam hubungannnya dengan sesama makhluk. Seorang pengikut paham jabr adalah orang mukmin yang negatif dalam hidupnya.9 Salah satu ciri perbuatannya ia selalu bersandar pada orang lain, meskipun orang lain itu sebenarnya lebih lemah dari pada dirinya. Bagaimanapun juga, paham jabr sesuai dengan taklid, yang kedua-duanya menjadi kelemahan dalam hidup. 10

Tampaknya bagi Muhammad Abduh paham jabr telah menyebabkan manusia menjadi lemah dan kehilangan daya kreasi dan posisi dalam hidupnya. Oleh karena itu Muhammad Abduh menyerukan paham kebebasan bagi manusia, agar seorang muslim hidupnya menjadi orang yang kreatif.

4 Ibid., h.169

5 Nashr Hamid Abu Zaid, Menalar Firman Tuhan: Wacana Majas dalam Al-Qur'an menurut Mu 'tazilah, diterjemahkan oleh:Abdurrahman Kasdi dan Hamka Hasan dari Al-Ittijah Al-Aqli fi al-Tafsir: Dirash fi Qadhiyyat al-Majazfi al-Qur’an `inda Mu `tazilah, (Bandung: Penerbit Mizan, 2003) h.318

6 Ibid.

7 Ibid., h.319

8 Muhammad al-Bahi, Al-Fikr al-Islam al-Hadits wa shilatuh bi al-Isti`mar al-Gharib, (ttp: Mathba`ah Muckaimar, 1957) cet.I, h.118-119

9 Ibid.

10 Ibid. 
Kalau Harun Nasution Mengatakan, bahwa paham teologi 'Asyariyah (tradisional) adalah salah satu faktor yang memperlambat kemajuan dan pembangunan, sementara Muhammad Abduh, mensinyalir penganut paham jabr menyebabkan manusia kehilangan kreasi dan posisi dalam hidupnya.

Dari pendapat kedua tokoh tersebut, dipahami bahwa salah satu sebab kemunduran umat Islam adalah karena mereka menganut paham jabr. Masalah ini juga dibawa kepada implikasi di bidang politik, bahwa salah satu penyebab kemunduran umat Islam di bidang politik adalah paham jabr. Paham jabr dapat menyebabkan manusia kehilangan daya juang karena senantiasa pasrah kepada nasib yang telah ditentukan Tuhan. Hal ini sekaligus memberikan legitimasi kepada penguasa untuk berlaku sewenang-wenang, dengan dalih apapun yang dilakukannya.

Sejalan dengan hal tersebut di atas, Murthadha Muthahhari mengemukakan bahwa, kesimpulan yang paling kuat dari corak pemikiran Asyariyah tentang keadilan Tuhan ialah bahwa perbuatan yang dilakukan oleh orang yang zhalim pada hakekatnya, tidak dilakukan olehnya, melainkan dilakukan oleh Allah.11 Karena semua perbuatan adalah milik Allah. Jadi, ketika perbuatan itu perbuatan Allah, maka perbuatan tersebut tidak termasuk kezhaliman, melainkan termasuk keadilan itu sendiri. Dengan demikian sebenarnya mereka tidak mensucikan Allah, melainkan mensucikan orang-orang zhalim, dan memaafkan perbuatan mungkar mereka.12

Dari Uraian-uraian tersebut di atas, dapat dipahami bahwa implikasi paham kekuasaan Tuhan yang dikaitkan dengan perbuatan manusia dari aliran-aliran teologi dalam Islam, utamanya Qadariyah-Mutazilah dan Jabariyah-Asyariyah, meliputi seluruh aspek kehidupan umat, baik yang menyangkut kehidupannya di dunia maupun kehidupannya di akhirat, baik kehidupan ibadahnya maupun kehidupan muamalahnya.

\section{B. Hikmah dan Dampak Adanya Taqdir}

Allah Swt. mentakdirkan segala perkara yang akan terjadi pada alam semesta ini. Karenanya, keimanan pada taqdir Allah ini merupakan bagian terpenting dalam konsep keimanan kepada Allah. Yang jelas, Allah telah mengatur seluruh proses semesta ini, mulai dari hal yang menyangkut penciptaan alam semesta ini, hubungan manusiawi, hubungan manusia dengan alam semesta, dan seterusnya.

Pada dasarnya, keimanan pada takdir Allah ini, baik taqdir baik maupun buruk, merupakan suatu landasan keimanan. Karena itu, Rasulullah saw. menjadikan keimanan tersebut sebagai rukun tersendiri. Dari keimanan tersebut banyak hikmah yang dapat diambil oleh orang beriman.

11Murthadha Muthahhari,

12 Ibid. 
1. Munculnya kekuatan tekad dan hilangnya keraguan. Dalam komunitas manusia, tidak akan ada tekad yang setajam dan sekuat tekadnya seorang mukmin dalam menghadapi taqdir Allah Swt.. Jika seorang mukmin menghadapi berbagai permasalahan, lantas berniat untuk meminta nasehat kepada orang lain dan beristikharah kepada Tuhannya, dia akan memiliki kemantapan hati serta berniat dan mengerjakan segala perbuatan dan pekerjaan tanpa ragu dan takut. Dia sangat meyakini bahwa seluruh situasi dan kemungkinan yang akan terjadi itu betul-betul di luar kemampuan manusia. Semuanya merupakan bagian dari perkara yang ada dalam pengetahuan dan taqdir Allah. Dia sangat yakin bahwa Allah akan menolongnya dengan memilih yang terbaik untuknya. Jika merasa bahwa Allah memudahkan pelaksanaan suatu niat, yakin bahwa Allah akan memberi padanya sesuatu yang terbaik, dan memelihara-Nya dari keburukan-keburukan.

2. Berani menghadapi kematian. Jiwa itu tidak akan ditimpa kematian kecuali dengan izin dan ketetapan Allah Swt.. Sebagaimana Firman Allah:

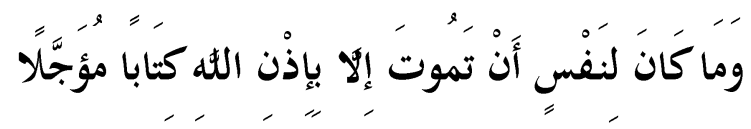

Terjemahnya:

"Sesuatu yang bernyawa tidak akan mati melainkan dengan izin Allah, sebagai ketetapan yang telah ditentukan waktunya”. (QS. Āli Imrān/3:145)

Karena itu, tidak mungkin seorang mukmin sejati sesumbar bahwa dia tidak akan pernah mati, untuk itu pula Allah berfirman:

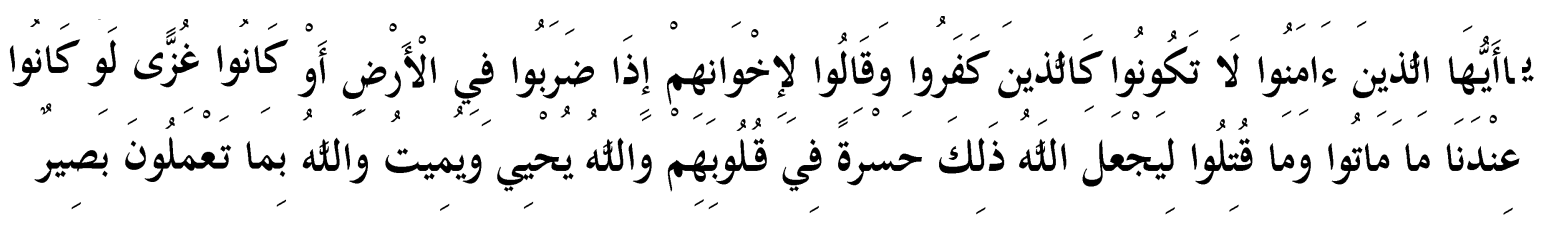

Terjemahnya:

"Hai orang-orang yang beriman, janganlah kamu seperti orang-orang kafir (orang-orang munafik) itu, yang mengatakan kepada saudara-saudara mereka apabila mereka mengadakan perjalanan di muka bumi atau mereka berperang: "Kalau mereka tetap bersama-sama kita tentulah mereka tidak mati dan tidak dibunuh." Akibat (dari perkataan dan keyakinan mereka) yang demikian itu, Allah menimbulkan rasa penyesalan yang sangat di dalam hati mereka. Allah menghidupkan dan mematikan. Dan Allah melihat apa yang kamu kerjakan”. (QS.Ālụ Imrān/3:156)

Jika seorang mukmin dididik untuk berani menghadapi maut, dia akan berani menghadapi segala tantangan hidup, baik berupa kehilangan harta kekayaan, kedudukan, pangkat dan jabatan, atau menghadapi musibah dan penyakit karena dia sangat yakin bahwa itu semua adalah rangkaian taqdir Allah Swt.. Demikian itu sebagai seorang muslim sepatutnya meyakini bahwa apa yang ditaqdirkan Allah, entah itu baik ataupun buruk, dan meyakini bahwa kematian seseorang pasti 
datang pada saat yang telah ditentukan,13 dan hal ini tidak seorang pun yang sanggup menambah ataupun mengurangi umurnya, seperti yang terdapat dalam QS. al-Arāaf/:34:

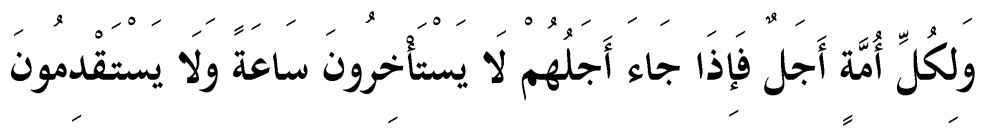

Terjemahnya:

"Tiap-tiap umat mempunyai batas waktu; maka apabila telah datang waktunya mereka tidak dapat mengundurkannya barang sesaatpun dan tidak dapat (pula) memajukannya".

Hal inilah yang menjadikan kaum muslimin sejak dulu hingga sekarang dalam berbagai peperangannya, mulai perang badar sampai perang Irak, tidak peduli apakah mereka akan mati dalam peperangan. Mereka yakin dengan firman Allah Swt..:

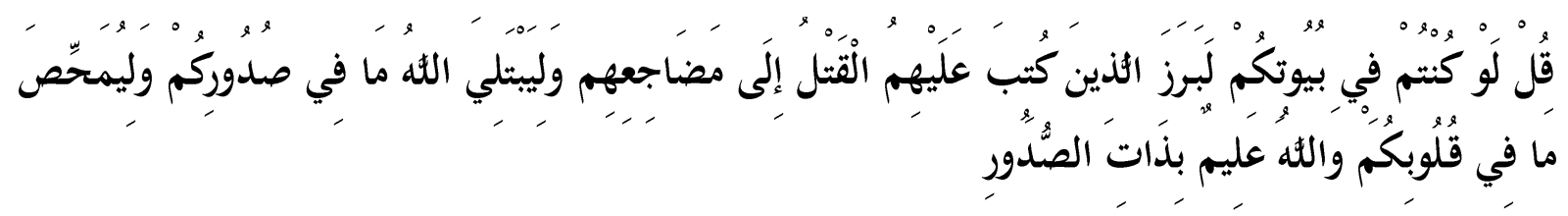

Terjemahnya:

"Katakanlah: "Sekiranya kamu berada di rumahmu, niscaya orang-orang yang telah ditakdirkan akan mati terbunuh itu ke luar (juga) ke tempat mereka terbunuh". Dan Allah (berbuat demikian) untuk menguji apa yang ada dalam dadamu dan untuk membersihkan apa yang ada dalam hatimu. Allah Maha Mengetahui isi hati”. (QS.Ālu Imrān/3:154)

Pada masa awal-awal perkembangan Islam, kaum muslimin menyebarkan dakwah dengan memperluas wilayah kekuasaannya hingga ke berbagai pelosok dunia. Banyak sekali negara-negara yang ditaklukkan. Keberhasilan dan kegagalan mereka dalam menguasai dunia sangatlah mengagumkan. Kekuasaan Islam kala itu terbentang luas, sekalipun persenjataan mereka tidak begitu lengkap dan jumlah personil tidak terlalu banyak.14 Hal ini bisa diambil kesimpulan "sementara" bahwa pemikiran mengenai taqdir pada saat itu sangat memberikan arti dan semangat juang.

1. Tidak menyesali atau merasa rugi terhadap sesuatu yang tidak dapat diraih. Seorang mukmin tidak akan pernah meratapi hal-hal yang telah terjadi melalui penyesalan atau kesedihan yang berlebihan. Sebab dia menyadari bahwa penyesalan itu tidak akan dapat mengembalikan apa yang tidak dapat diraihnya itu. Dia hanya bertekad untuk semaksimal mungkin meraih apa yang telah ditetapkan Allah untuknya dan tidak ada dalam benaknya upaya untuk menghalangi taqdir Allah selama sesuatu telah terjadi. Untuk sesuatu yang membuatnya salah langkah, dia senantiasa mengambil hikmah dari semuanya.

2. Mendorong orang untuk bersikap berani dalam menegakkan keadilan dan kebenaran. Ia tidak akan takut dan gentar menghadapi resiko dan bahaya yang mengancamnya, seperti kemiskinan dan kematian, karena ia yakin bahwa kematian, rezeki, nasib dan sebagainya semua di tangan Allah, hal ini tergambar dalam firman Allah Swt.., QS. al-Tawbah/9:51:

13 Yusuf Qaradhawi, Al-Imân bi al-Qadr, (Kairo: Maktabah Wahbah, 2000), h.192

14 Ibid. 
Terjemahnya:

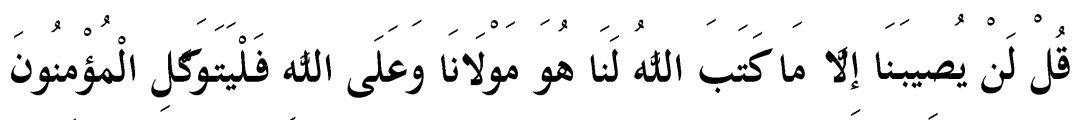

"Katakanlah: "Sekali-kali tidak akan menimpa kami melainkan apa yang telah ditetapkan oleh Allah bagi kami. Dialah Pelindung kami, dan hanyalah kepada Allah orang-orang yang beriman harus bertawakkal".

Adapun mengenai kematian, rezeki dan nasib yang menimpa pada seseorang, dapat dilihat dalam QS.Yūnus/10:49, Hūd/11:6, al-Hadid/57:2215

3. Optimisme, rela, dan menghindari upaya pencarian penyebab musibah melalui ramal-meramal. Tidak mungkin dia mencari penyebab musibahnya melalui suara burung hantu, atau seperti ramalan kaum kafir. Tentang itu Allah Swt.. Mengisahkan dalam ayat di bawah ini;

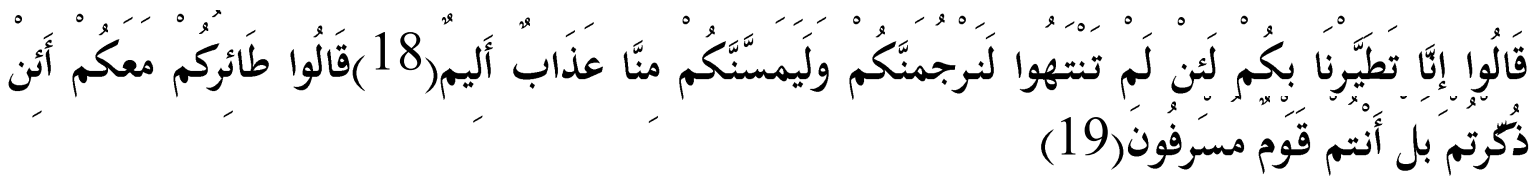

Terjemahnya:

"Mereka menjawab: "Sesungguhnya kami bernasib malang karena kamu, sesungguhnya jika kamu tidak berhenti (menyeru kami), niscaya kami akan merajam kamu dan kamu pasti akan mendapat siksa yang pedih dari kami".(18) Utusan-utusan itu berkata: "Kemalangan kamu itu adalah karena kamu sendiri. Apakah jika kamu diberi peringatan (kamu mengancam kami)? Sebenarnya kamu adalah kaum yang melampaui batas".(19) (QS.Yāsin/:18-19)

Dalam riwayat Abu Dāud dikatakan bahwa Urwah bin Amar telah menuturkan sebuah ramalan kesialan dihadapan Rasulullah saw.. Mendengar itu, Rasulullah saw. Bersabda:

$$
\begin{aligned}
& \text { وعن عروة بن عامرقال: ذكرت الطيرة عند رسول الله فقال: أحسنها الفأل, ولا ترد مسلما, فإذا رأي }
\end{aligned}
$$

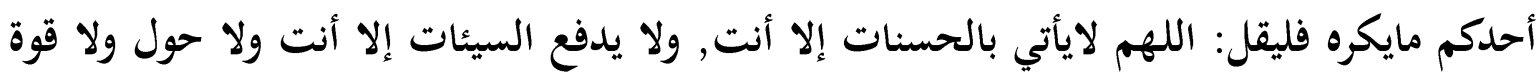

$$
\begin{aligned}
& \text { إلا بك. (رواه أبو داؤد بإسناد صحيح) }
\end{aligned}
$$

15 QS.Yûnus/10:49:

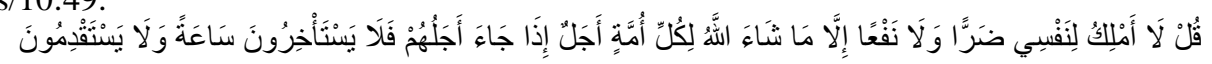

'Katakanlah: "Aku tidak berkuasa mendatangkan kemudharatan dan tidak (pula) kemanfa atan kepada diriku, melainkan apa yang dikehendaki Allah." Tiap-tiap umat mempunyai ajal. Apabila telah datang ajal mereka, maka mereka tidak dapat mengundurkannya barang sesaatpun dan tidak (pula) mendahulukan (nya)”.

QS.Hûd/11:6:

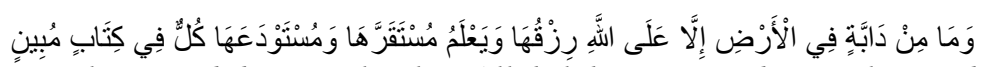

"Dan tidak ada suatu binatang melatapun di bumi melainkan Allah-lah yang memberi rezkinya, dan Dia mengetahui tempat berdiam binatang itu dan tempat penyimpanannya. Semuanya tertulis dalam kitab yang nyata (Lauh Mahfuzh)".

QS.Al-Hadîd/57:22:

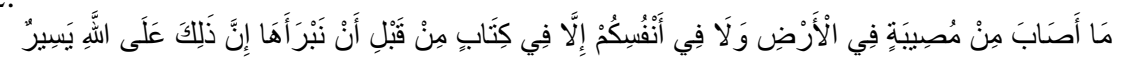

"Tiada suatu bencanapun yang menimpa di bumi dan (tidak pula) pada dirimu sendiri melainkan telah tertulis dalam kitab (Lauh Mahfuzh) sebelum Kami menciptakannya. Sesungguhnya yang demikian itu adalah mudah bagi Allah". 
Artinya:

"Dari Urwah bin Amir, dia berkata: Saya telah menuturkan sebuah ramalan kepada Rasulullah saw., maka beliau bersabda: "Sebaik-baiknya ramalan adalah pengharapan yang baik. Ramalan tidak akan menggamangkan seseorang muslim. Apabila salah seorang diantara kamu melihat sesuatu yang tidak disukainya, maka katakanlah: "Ya Allah, tiada yang mendatangkan berbagai kebaikan selain Engkau dan tiada yang dapat menolak berbagai keburukan selain Engkau, tiada upaya dan kekuatan kecuali dengan pertolonganMu".

Tidak jarang manusia yang measa jengkel terhadap penyakit. Padahal, jika kita renungkan lebih jauh, ketika kita tengah menghadapi penyakit, banyak waktu yang dapat kita gunakan untuk berzikir atau instropeksi diri, sehingga kita berniat untuk memperbaiki akhlak dan menebus berbagai kesalahan.

4. Semua dampak yang terjadi karena beriman kepada taqdir Allah itu, mendidik kaum muslimin untuk bernalar dan tidak mengekspoitasi hawa nafsu dalam mencari penyebab suatu persoalan. Seorang mukmin akan mengetahui bahwa segala fenomena alam semesta ini berkisar antara kebaikan dan keburukan. Dengan demikian, dia harus waspada serta hanya memilih kebaikan dan membuang keburukan.

5. Sabar ketika ditimpa musibah, adalah salah satu buah iman kepada taqdir. Sebab orang yang beriman kepada taqdir tidak akan mudah dikuasai oleh oleh peasaan duka ataupun sedih, dan dia juga tidak bisa dikendalikan oleh rasa marah ataupun kesal, bahkan dia akan menyambut setiap musibah dengan jiwa yang tegar. Tidak lemah hati dan tidak gentar menghadapi cobaan.16

Namun yang hendaknya kita renungkan dalam-dalam ialah penegasan dalam firman Allah,17 itu bahwa hikmah atau makna ajaran tentang adanya takdir itu ialah agar kita tidak menjadi putus asa karena mengalami kegagalan, dan sebaliknya, janganlah kita menjadi sombong atau tidak tahu diri karena mengalami keberhasilan. Dan sungguh itulah emang kelemahan manusia.18 Yaitu mudah putus asa kalau gagal, dan mudah lupa daratan kalau sukses. Padahal kalau saja kita insyaf bahwa tidk ada kegagalan yang telah terjadi, kecuali atas kehendak Tuhan jua sesuai dengan rencana-Nya. Sebagaimana jua tidak ada keberhasilan, kecuali sebagai wujud rencana Ilahi jua.19

16 QS. Al-Baqarah/2:155

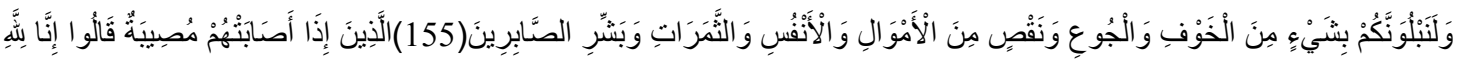

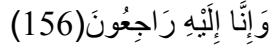

"Dan sungguh akan Kami berikan cobaan kepadamu, dengan sedikit ketakutan, kelaparan, kekurangan harta, jiwa dan buah-buahan. Dan berikanlah berita gembira kepada orang-orang yang sabar,(155) (yaitu) orang-orang yang apabila ditimpa musibah, mereka mengucapkan, "Innaa lillaahi wa innaa ilaihi raaji “un"(156)

17QS. al-Hadid/57:22-23

18Nurcholish Madjid, Pintu-Pintu Menuju Tuhan, (Jakarta: Penerbit Paramadina, 2002) cet.VI, h. 24

19Ibid. 
Karena itu sebaik-baiknya sikap ketika mengalami kegagalan ialah rela (ridha') kepada Allah atas segala rencana-Nya, dan ketika mengalami keberhasilan ia bersyukur kepada Allah Swt.. Maka kita tidak terlalu menjadi sedih dan berputus asa sehingga kehilangan daya untuk menghadapi masa depan, juga tidak terlalu membanggakan diri karena prestasi kita sehingga kehilangan keseimbangan jiwa, adalah sumber tenaga dan semangat untuk menghadapi hidup.20

Paham Jabariyah, kalau dipegangi secara ekstrim, akan menimbulkan hilangnya tanggung jawab manusia atas perbuatannya. Jika semua yang akan terjadi ditentukan oleh Allah sejak azali, mengapa manusia harus bertanggung jawab atas perbuatannya?. Kalau manusia sudah kehilangan rasa tanggung jawab, maka akibatnya ia akan berbuat semau-maunya sendiri. Hukum, normanorma, aturan-aturan dan semisalnya tidak ada lagi gunanya. Keberadaan manusia pun terancam karenanya.

Salah satu akibat yang berbahaya dalam faham determinisme kepada masyarakat bahwa determinisme membuat para penindas arogan lebih mudah untuk menahan dan menekan orangorang yang tertindas dan lebih sulit bagi orang yang tertindas untuk mempertahankan diri mereka.

Dengan mempergunakan determinisme sebagai sebuah dalih, sang penindas mengingkari semua tanggung jawab demi tindakan-tindakannya yang kejam, dia bisa mengklaim dirinya bahwa tangannya adalah tangannya Allah dan mensifatkan semua pelanggaran kepada Allah.

Dari sini, orang dapat mengatakan bahwa kepunahan atau kekacauan yang diperkirakan dapat timbul akibat tidak adanya rasa tanggung jawab itu tergantung juga pada ketentuan Allah. Kalau Allah menghendaki, tidak ada daya yang mampu menghalangi, dan tidak ada pun yang mampu mewujudkannya.

Sikap pasif dalam kehidupan dunia ini, akan melahirkan ekstriminitas paham Jabariyah. Jika semua telah ditentukan Allah sebelumnya, maka tidak ada kemampuan sama sekali bagi manusia untuk mengubahnya. Oleh karena itu, sikap yang paling tepat adalah meneriam apa adanya segala yang etrjadi itu. Usaha papaun hanya akan berakhir dengan sia-sia. Orang dapat mengatakan bahwa, usaha msnusia masih pelu dilakukan, karena tidak ada mannusia yang tahu apa yang akan ditentuakan Alllah untuknya sebelum menjadi kenyataan.21

Dengan sikap menyerah seperti ini, potensi yang ada pada manusia tidak akan dapat berkembang. Kemampuan berpikir yang darinya akan timbul penemuan-penemuan baru dalam bidang ilmu dan teknologi tidak akan pernah dicapai manusia yang bersikap seperti ini. Akibat selanjutnya adalah ketertinggalan yang serius dalam kehidupan ini du dunia yang menyebabkan fungsi manusia tidak dapat terwujud. Keadaan alam yang melingkungi manusia dengan sikap 
seperti itu tidak akan mengalami perubahan dari pihak manusia. Manusia tidak akan menjadai penguasa alam, tetapi sebaliknya, malah tergantung pada lingkungannya. Dengan begitu ia tidak berbeda dengan hewan. 22

Adapun paham Qadaiyah, bila diterapkan secara ekstrim akan menimbulkan pula kesulitankesulitan. Dengan kepercayaan yang besar pada kemampuannya untuk mengatur sendiri nasibnya, manusia akan terjerumus dalam kesombongan. Ia akan merasa serba mampu dalam kehidupannya. Lahirlah gagasan Ubermensch tak lain disebabkan oleh kesombongan manusia yang didasrkan atas kemampuannya sendiri untuk mengatur dunia sekitarnya. Tuhan lalu dianggap sudah mati. Artinya, manusia tidak lagi membutuhkan Tuhan dalam menyiasati kehidupannya di dunia,23 manusia benar-benar bisa mandiri sepenuhnya. Dalam keadaan terjempit, ia selalu cenderung mencari sandaran yang berupa kekuatan gaib yang mampu menyelamatkannya dari kesulitan itu.

Paham qadariyah juga dapat menyebabkan pemujaan yang keterlaluan pada akal dan penalaran. Bahwa peran akal sangat penting dalam kehidupan manusia. Namun pemujaan yang keterlaluan kepada akal akan menempatkan akal pada kedudukan yang terpenting dalam keidupan, dan akhirnya akal dianggap segala-galanya dalam kehidupan. Di silah timbul kesulitan. Tidak seluruhnya aspek kehidupan dapat dikuasai akal. Hal-hal kebetulan seringkali mengejutkan perhitungan. 24

Hal lain juga timbul dari ekstrimitas paham Qadariyah adalah hilangnya pegangan manusia manakala jalan yang ditempuh berdasarkan akal mengalami kebuntuan. Kalau akal dijadikan satusatunya pedoman, maka disatu saat akal kehabisan jalan, tidak ada lagi pegangan bagi manusia. Dalam keadaan seperti ini, keberadaan manusia akan sangat terganggu. Hanya dengan menyadari keterbatasan wilayah akal, lalu menyandarkan diri kepada Allah Swt.. dalam hal-hal yang di luar wilayahnya itulah manusia bisa membebaskan diri dari kesulitan.

\section{Cara Menyikapi Taqdir}

Berbicara mengenai taqdir, kita tidak boleh berburuk sangka kepada Allah Swt.. Masalah taqdir adalah masalah yang sangat pelik, karena selalu ada yang ingin membelokkan, ingin mengganjal kita kewawasan yang keliru, yaitu syaitan yang terkutuk itulah yang berusaha membawa kita kewawasan (vision) atau pola pikir yang keliru, oleh karena itu harus ada alternatif pikiran atau pemahaman yang mendasar yang mampu mendudukkan satu persatu. Untuk itulah, maka alternatif (pilihan) dasar vision taqdir adalah bahwasanya, sangatlah keliru jika seseorang berasumsi bahwa

22Ibid.

23Tentang paham Ubermensch ini, lihat A.Sudiarja, "Pergulatan Manusia dengan Allah dalam Antripologi Nietzsche” dalam M.Sastrapratedja (ed.), Manusia Multi Demensional, (Jakarta: Gramedia, 1983) cet.II, h.9-11

24Sebagai contoh, kesandhung ing arata, kejentus ing awang-awang (Kesandung di jalan rata, dan terbentur di udara lapang). Hal ini menunjukkan kepada hal-hal; yang menurut perhituntgan akal tidak akan terjadi, tetapi dalam kenyataan hal ini terjadi. 
manusia itu seperti boneka atau komputernya Allah Swt.., berkaitan dengan ditetapkannya nasib baik dan buruknya seseorang, miskin dan kaya, bodoh dan pintar, syurga dan neraka. Karena itu Allah tidak pernah mempermainkan ciptaan-Nya seperti permainan dukun sesat dengan santetnya, dan ini diberitakan oleh Allah dalam firman-Nya:

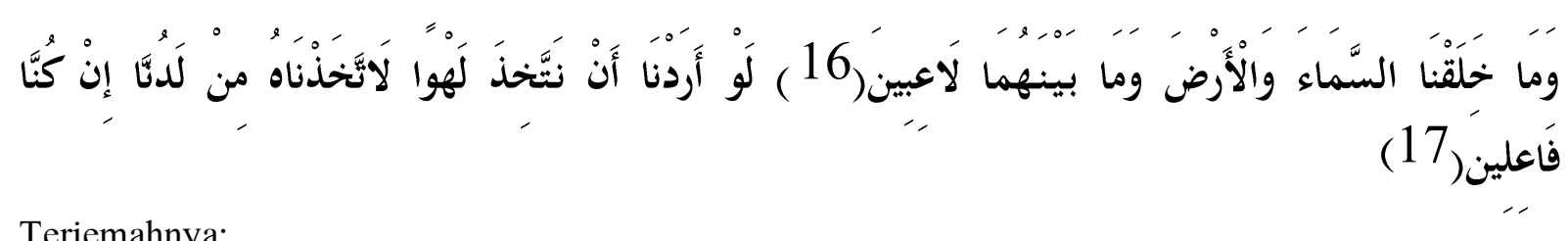

Terjemahnya:

"Dan tidaklah Kami ciptakan langit dan bumi dan segala yang ada di antara keduanya dengan bermain-main.(16) Sekiranya Kami hendak membuat sesuatu permainan (isteri dan anak), tentulah Kami membuatnya dari sisi Kami. Jika Kami menghendaki berbuat demikian, (tentulah Kami telah melakukannya”.(17) (QS.al-'Anbiya'/:16-17)

Juga sangat keliru, jika orang beranggapan bahwa sudah ditetapkan akan seseorang itu masuk neraka kendatipun itu semua ada dalam ketetapan yang dimiliki Allah tanpa melihat akibat orang tersebut memilih jalur yang sesat. Kalau benar kenyataannya demikian, berarti Allah telah berbuat zhalim kepada ciptaan-Nya. Padahal Allah berfirman:

Terjemahnya:

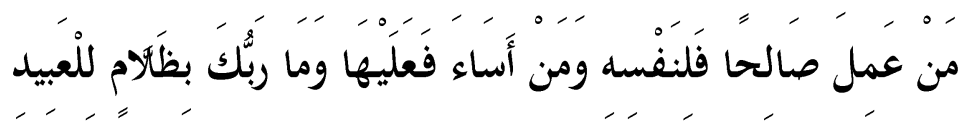

"Barangsiapa yang mengerjakan amal yang saleh maka (pahalanya) untuk dirinya sendiri dan barangsiapa yang berbuat jahat maka (dosanya) atas dirinya sendiri; dan sekali-kali tidaklah Tuhanmu menganiaya hamba-hamba (Nya)". (QS.Fushshilat/41:46)

Terjemahnya:

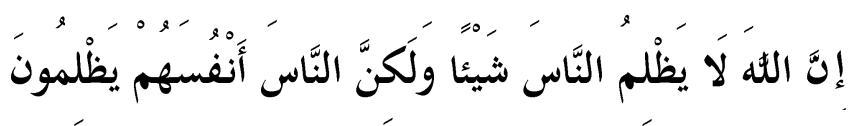

"Sesungguhnya Allah tidak berbuat zalim kepada manusia sedikitpun, akan tetapi manusia itulah yang berbuat zalim kepada diri mereka sendiri”. (QS.Yūnus/10:44)

Menurut ayat-ayat di atas, berpengertian bahwa manusia tidak boleh, bahkan bisa syirik, mengatakan "ini sudah taqdir" terhadap keadaan yang menimpa dirinya, selama dia masih mempunyai akal (yakni tenaga penimbang, berpikir berdasarkan hasil indera) yang dapat membedakan antara benar dan salah.

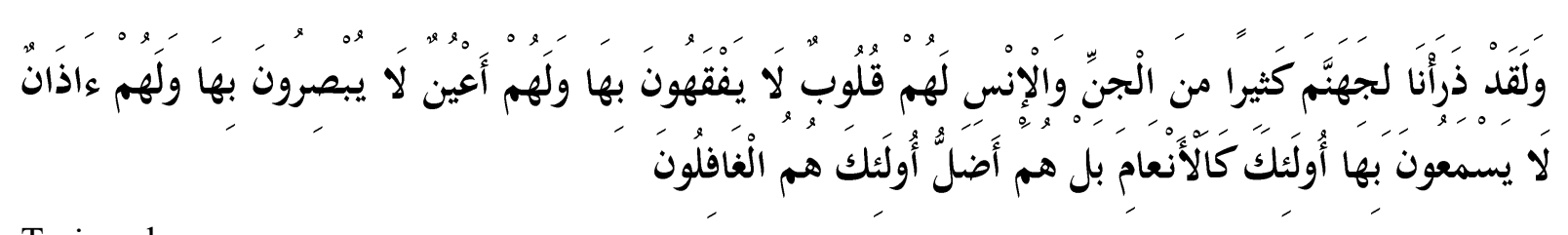

Terjemahnya:

"Dan sesungguhnya Kami jadikan untuk isi neraka Jahannam kebanyakan dari jin dan manusia, mereka mempunyai hati, tetapi tidak dipergunakannya untuk memahami (ayat-ayat Allah) dan mereka mempunyai mata (tetapi) tidak dipergunakannya untuk melihat (tanda-tanda kekuasaan Allah), dan mereka mempunyai telinga (tetapi) tidak dipergunakannya untuk 
mendengar (ayat-ayat Allah). Mereka itu sebagai binatang ternak, bahkan mereka lebih sesat lagi. Mereka itulah orang-orang yang lalai”. (QS.al- Avāaf /7:197)

Dari ayat di atas dapat dipahami bahwa sebab tibanya kemiskinan, kemalangan, sifat jahat, kesesatan itu semua adalah akibat perbuatan kedurhakaan dan keluar dari ajaran-ajaran Allah yang sebenarnya. Jadi bukanlah suatu taqdir. Sangatlah tepat Allah berfirman:

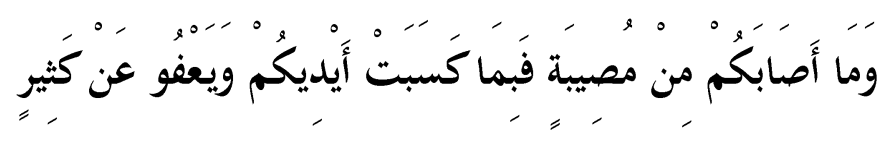

Terjemahnya:

"Dan apa musibah yang menimpa kamu maka adalah disebabkan oleh perbuatan tanganmu sendiri, dan Allah memaafkan sebagian besar (dari kesalahan-kesalahanmu)". (QS.Syūra/:30)

Lebih umum lagi:

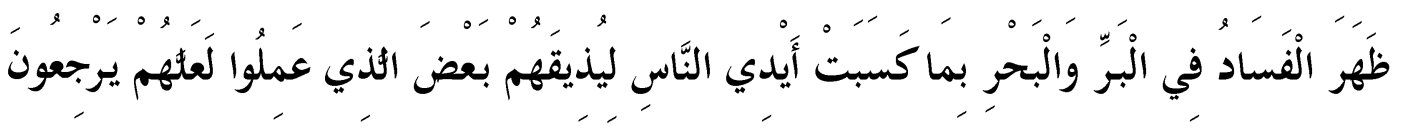

Terjemahnya:

"Telah nampak kerusakan di darat dan di laut disebabkan karena perbuatan tangan manusia, supaya Allah merasakan kepada mereka sebahagian dari (akibat) perbuatan mereka, agar mereka kembali (ke jalan yang benar)". (QS.al-Rūm/30:41)

Orang yang beriman kepada Allah dan hari akhir tidak akan merasa takut dan susah, demikian Allah menjamin. Allah menjamin orang yang bertakwa kepada-Nya dengan diberi jalan keluar dari segala kesulitan yang dialaminya dan diberi rezeki dari arah yang tidak disangka-sangkanya, sebagaimana firman-Nya dalam QS.Al-Maidah/5:69;25

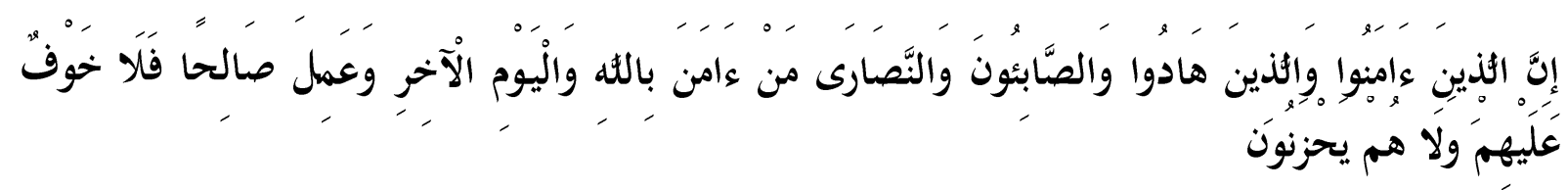

Terjemahnya:

"Sesungguhnya orang-orang mu'min, orang-orang Yahudi, Shabiin dan orang-orang Nasrani, siapa saja (di antara mereka) yang benar-benar beriman kepada Allah, hari kemudian dan beramal saleh, maka tidak ada kekhawatiran terhadap mereka dan tidak (pula) mereka bersedih hati".

Dan QS.al-Ṭalaq/65:2-3;

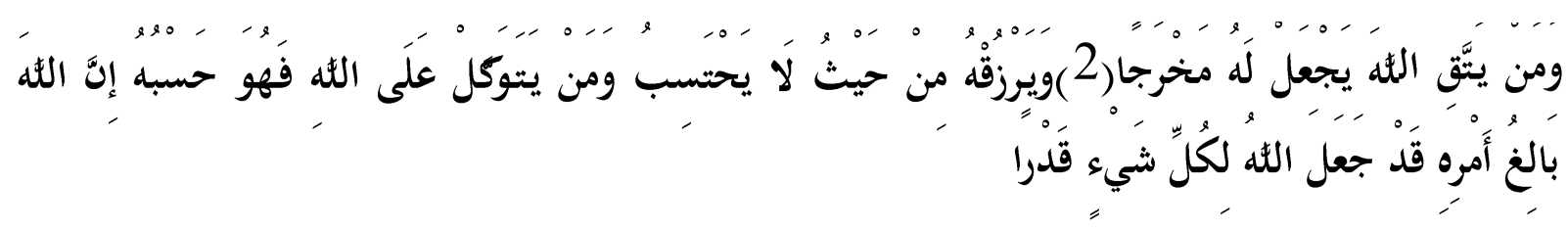

$25 \mathrm{Hal}$ ini bisa juga dilihat dalam berbagai ayat yaitu: QS.al-Baqarah/2:38, 62, 112, 274, dan 227. QS.Ali Imran/3:170, QS.al-An`am/6:48, QS.al-A`raf /7:35, Yunus/10:62, QS.al-Zumar/39:61, dan QS.al-Ahqaf/64:13. 
Terjemahnya:

"Barangsiapa yang bertakwa kepada Allah niscaya Dia akan mengadakan baginya jalan ke luar.(2) Dan memberinya rezki dari arah yang tiada disangka-sangkanya. Dan barangsiapa yang bertawakkal kepada Allah niscaya Allah akan mencukupkan (keperluan) nya. Sesungguhnya Allah melaksanakan urusan (yang dikehendaki) Nya. Sesungguhnya Allah telah mengadakan ketentuan bagi tiap-tiap sesuatu".

Seberapapun kebebasan dan kemampuan manusia untuk melakukan hal-hal ikhtiari, hasil dan dari perbuatannya tetap merupakan teka-teki yang baru dapat diketahuinya setelah terwujud. Kepercayaan bahwa hal-hal yang gaib, yang sangat banyak dalam kehidupan ini, adalah milik Allah semata, dan hal ini sangat bermanfaat untuk menguatkan dan menabahkan hati orang beriman.

Apa yang terjadi di langit dan di bumi dan yang menimpa manusia sudah ada ketentuqannya sejak zman azali. Hal ini harus dipercayai manusia, agar supaya tidak terlalu susah dan putus asa manakala luput darinya apa yang dishakannya, dan tidak terlalu gembira kalau mendapatkan keberhasilan. Hal ini ditegaskan dalam al-Qur'an

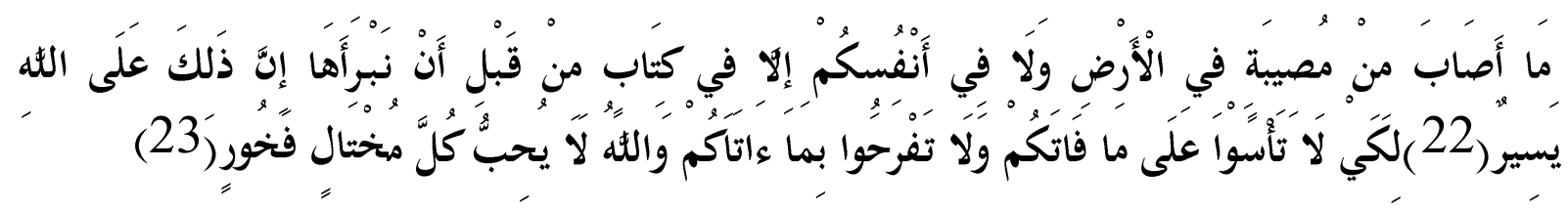

Terjemahnya:

"Tiada suatu bencanapun yang menimpa di bumi dan (tidak pula) pada dirimu sendiri melainkan telah tertulis dalam kitab (Lauh Mahfuzh) sebelum Kami menciptakannya. Sesungguhnya yang demikian itu adalah mudah bagi Allah.(22) (Kami jelaskan yang demikian itu) supaya kamu jangan berduka cita terhadap apa yang luput dari kamu, dan supaya kamu jangan terlalu gembira terhadap apa yang diberikan-Nya kepadamu. Dan Allah tidak menyukai setiap orang yang sombong lagi membanggakan diri”. (23) QS.al-Hadid/57:22-23

Kata musibah dalam ayat di atas, mestinya tidak hanya dipahami sebagai hal yang berat atau bencana. Terkandung pula di dalamnya keberhasilan dan kegagalan usaha di samping bencana yang berasal dari kekuatan napapun di luar manusia. Manusia tidak mempunyai kemungkinan untuk melepaskan diri dari musibah itu jika sudah terjadi padanya. Oleh karena itu, sikap pasrah, menyerah diri dari kepada kebijaksanaan Allah Swt.. sangat menguntungkannya pada saat itu. Demikian pula kenikmatan yang datang. Manusia tidak boleh terlalu bangga dengan menganggapnya sbagai kemestian dari usahanya. Ada faktor-faktor di luar dirinya dan ikut mewujudkannya atau bahkan menentukan terwujudnya atau tidak terwujudnya usaha itu.26

Hal ini sama sekali tidak berarti, bahwa manusia tidak boleh berusaha. Konteks kepercayaan kepada ketentuan yang telah ada sebelumnya ini menunjukkan bahwa manusia mesti mengingatnya setelah semua itu terjadi, bukan sebelumnya. Memang tidak ada salahnya kalau itu diingat pada awal sebuah usaha, asalkan tidak menyebabkan kelemahan semangat. Kemestian mengingatnya di akhir 
sebuah usaha, atau lebih tepatnya setelah diketahui keberhasilan atau kegagalannya yang berarti peringatan akan keterbatasannya usaha manusia dan kekuasaannya.

Selain itu, yang akan di nilai dihadapan Allah, yang mesti dipertanggung jawabkan manusia, bukanlah keberhasilan usahanya di dunia, melainkan kebaikan usahanya. Kebaikan bukan berarti bahwa usaha itu tidak melekati kesalahan sama sekali, namun bahwa kesalahan-kesalahan yang ada padanya tidak dilakukan dengan kesengajaan. Sekalipun usaha manusia tidak berhasil, asal dilakukan dengan baik, akan dinilai baik oleh Allah Swt.. Di sinilah mesti diletakkan kebebasan manusia untuk menentukan sendiri jalannya.27

\section{KESIMPULAN}

Pada dasarnya, keimanan pada takdir Allah ini, baik taqdir baik maupun buruk, merupakan suatu landasan keimanan. Karena itu, Rasulullah saw. menjadikan keimanan tersebut sebagai rukun tersendiri. Dari keimanan tersebut banyak hikmah yang dapat diambil oleh orang beriman.

Semuanya merupakan bagian dari perkara yang ada dalam pengetahuan dan taqdir Allah. Dia sangat yakin bahwa Allah akan menolongnya dengan memilih yang terbaik untuknya. Jika merasa bahwa Allah memudahkan pelaksanaan suatu niat, yakin bahwa Allah akan memberi padanya sesuatu yang terbaik, dan memelihara-Nya dari keburukan-keburukan. Berani menghadapi kematian. Jiwa itu tidak akan ditimpa kematian kecuali dengan izin dan ketetapan Allah Swt.

Pada subtansinya (hakekatnya) manusia itu merdeka, bebas menentukan perbuatannya dengan usahanya sendiri dan kemerdekaan manusia itu sendiri adalah merupakan kadar atau taqdir Allah ayat-ayat di atas, itupun sebenarnya secara implisit memberikan pengertian bahwa usaha yang sifatnya merdeka, itulah yang menentukan akibatnya.

Al-Qur'an memberikan bekal yang cukup bagi mansia untuk bisa tetap tahan untuk bisa tetap tahan menghadapi dua sikap ektrim (Qadariyah/Mutazilah dan Jabariyah/Asyariyah) yang sama-sama membahayakan, kepercayaan kepada kemampuan diri yang terlalu besar dan bahwa mansia tidak mempunyai kemerdkaan sama sekali. Iman kepada Allah Swt.. dan selalu ingat kepada kekuasaan dan kasih sayang-Nya, setiap saat akan membebaskan manusia dari dua hal yang ektrim itu.

Dengan iman dan ingat kepada Allah, manusia sadar akan ketergantungannya kepada Allah Swt., dan karenanya manusia tidak merasa serba mampu. Dengan itu, ia akan selalu diingatkan oleh dirinya, bahwa yang tak terbatas hanyalah Allah, sedangkan mansuia terbatas, meskipun dengan keterbatasannya itu ia masih dapat berbuat banyak. Ia memang mempunyai kemungkinan yang sangat luas untuk berkembang, namun tetap saja kelemahan lekat dengan dirinya. Tanpa sandaran

27 Ibid., h. 140 
yang kuat, ia dapat setiap saat kehilangan kekuatan untuk menghadapi kenyataan hidup yang pahit.Iman dan selalu ingat kepada Allah atas segala kebesaran-Nya, akan memberikan harapanharapan baru setiap kali jalan usahanya tertutup dengan kegagalan.

\section{DAFTAR PUSTAKA}

Abu Zaid, Naṣr Hamid, Menalar Firman Tuhan: Wacana Majas dalam Al-Qur'an menurut Mutazilah, diterjemahkan oleh:Abdurrahman Kasdi dan Hamka Hasan dari Al-Ittijah Al-Aqli fi al-Tafsir: Dirash fi Qadhiyyat al-Majaz fi al-Qur'an inda Mutazilah, (Bandung: Penerbit Mizan, 2003).

Al-Bahi, Muhammad, Al-Fikr al-Islam al-Hadits wa shilatuh bi al-Isțimar al-Gharib, (ttp: Mathbaah Muckaimar, 1957).

Machasin, Menyelami Kebebasan Manusia.

Madjid, Nurcholish, Pintu-Pintu Menuju Tuhan, (Jakarta: Penerbit Paramadina, 2002).

Qardhawi, Yusuf, Al-Imān bi al-Qadr, (Kairo: Maktabah Wahbah, 2000).

Rahmat, Jalaluddin, Konsep Perbuatan Manusia Menurut Qur'an; Suatu Kajian Tafsir Tematik, (Jakarta: Bulan Bintang, 1992).

Sudiarja, "Pergulatan Manusia dengan Allah dalam Antripologi Nietzsche" dalam Sastrapratedja, M. (ed.), Manusia Multi Demensional, (Jakarta: Gramedia, 1983). 